
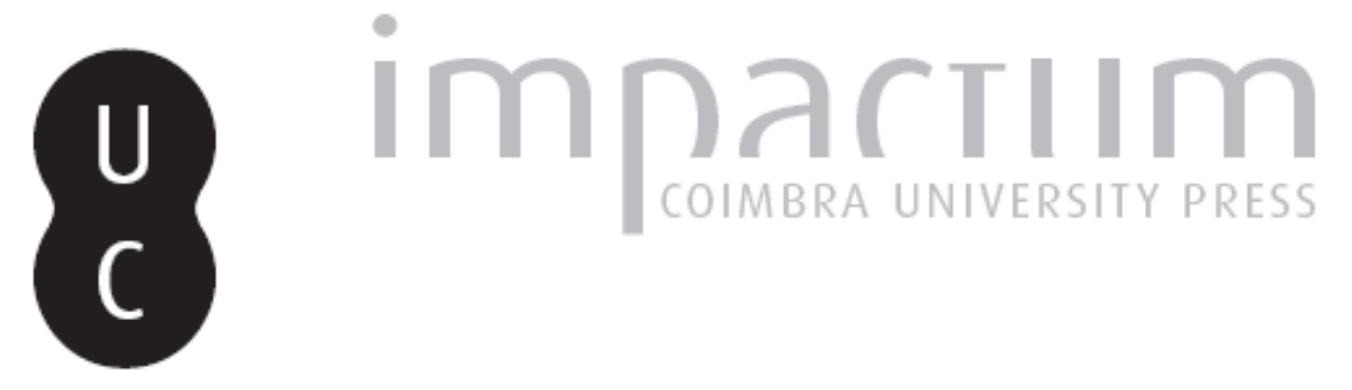

Uma abordagem estratégica das guerras e conflitos do século $\mathrm{XX}$

Autor(es): $\quad$ Santos, José Alberto Loureiro dos

Publicado por: Imprensa da Universidade de Coimbra

URL persistente:

URI:http://hdl.handle.net/10316.2/44997

DOI:

DOI:https://doi.org/10.14195/0870-4147_38_2

Accessed : $\quad$ 26-Apr-2023 13:25:04

A navegação consulta e descarregamento dos títulos inseridos nas Bibliotecas Digitais UC Digitalis, UC Pombalina e UC Impactum, pressupõem a aceitação plena e sem reservas dos Termos e Condições de Uso destas Bibliotecas Digitais, disponíveis em https://digitalis.uc.pt/pt-pt/termos.

Conforme exposto nos referidos Termos e Condições de Uso, o descarregamento de títulos de acesso restrito requer uma licença válida de autorização devendo o utilizador aceder ao(s) documento(s) a partir de um endereço de IP da instituição detentora da supramencionada licença.

Ao utilizador é apenas permitido o descarregamento para uso pessoal, pelo que o emprego do(s) título(s) descarregado(s) para outro fim, designadamente comercial, carece de autorização do respetivo autor ou editor da obra.

Na medida em que todas as obras da UC Digitalis se encontram protegidas pelo Código do Direito de Autor e Direitos Conexos e demais legislação aplicável, toda a cópia, parcial ou total, deste documento, nos casos em que é legalmente admitida, deverá conter ou fazer-se acompanhar por este aviso.

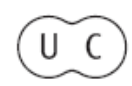



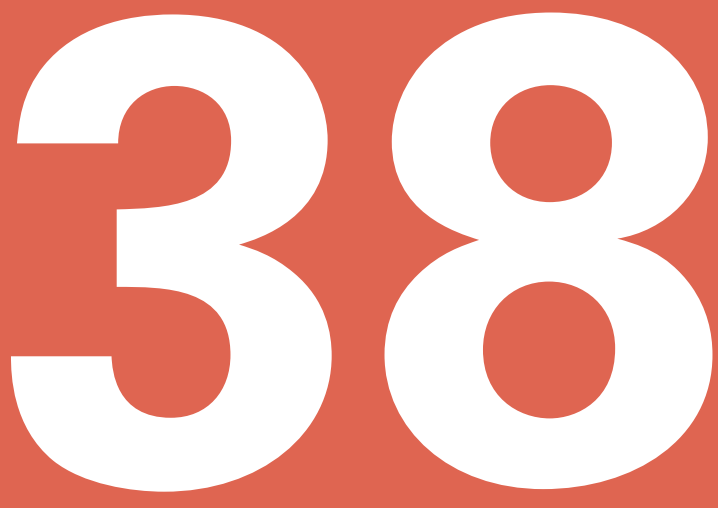

\section{Revista Portuguesa de História}

Faculdade de Letras da Universidade de Coimbra Instituto de História Económica e Social

Coimbra 08 


\title{
Uma abordagem estratégica das guerras e conflitos do Século XX
}

\author{
José Alberto Loureiro dos Santos
}

General (R)

\section{Os efeitos dramáticos do acelerado progresso tecnológico na capacidade de coagir}

1. Não existe qualquer outro século na História que se compare ao século XX, quanto ao ritmo de aperfeiçoamento dos instrumentos com que é possível fazer a guerra. Quando nos referimos à guerra em sentido integral, cuja designação mais comum é "conflito", envolvendo o emprego de diferentes vectores estratégicos de actuação - político, económico, cultural e/ou militar -, e quando pensamos apenas na condução militar das operações, a que vulgarmente se chama "guerra" - emprego de armas e equipamento militar.

Esta realidade repercutiu-se numa aceleração nunca vista da mudança das tácticas e estratégias utilizadas nos combates, não só nas estratégias operacionais, mas também nas genéticas e estruturais, nos conflitos como nas guerras.

Os sucessivos conflitos de dimensão significativa que se sucederam durante o século XX assinalaram outras tantas formas de os travar, o mesmo acontecendo com as principais guerras que neles tiveram lugar: Primeira Guerra Mundial, Segunda Guerra Mundial, Guerra-Fria, Guerras de Libertação Nacional, Conflitos de base cultural. 
Até cerca dos anos oitenta, os actores envolvidos nos conflitos eram de natureza estatal ou reclamavam assumir a direcção de um estado. Tiveram intervenção limitada os actores não estatais que procuravam coagir actores estatais. A partir dos anos oitenta, com o auge da globalização (económica, da informação/comunicação e cultural), aparecem actores não estatais com expressão transnacional, desencadeando conflitos de base cultural. Estes novos conflitos acompanham e respondem a uma alteração dramática no progresso tecnológico, que se veio a traduzir, nos instrumentos para fazer a guerra, na "revolução nos assuntos militares".

Os custos dos equipamentos militares foram subindo em flecha, assim como o nível científico que está por trás da sua invenção e desenvolvimento, e os custos logísticos das guerras convencionais atingiram valores apenas ao alcance de estados economicamente muito poderosos.

Dos gigantescos confrontos do século XX, que se caracterizaram por terem amplitude global, com seus efeitos em todos os cantos do mundo, resultaram muitos milhões de mortos $^{1}$; caíram e emergiram impérios; a ordem internacional (como relação de forças entre os vários centros de poder existentes no planeta), foi-se alterando; e elaboraram-se doutrinas geopolíticas e geoestratégicas, à medida que iam surgindo as sucessivas alterações políticas mundiais, na tentativa de explicar e justificar todos estes acontecimentos.

2. Para sistematizar a abordagem que pretendemos - avaliar os efeitos tácticos e estratégicos do acelerado progresso tecnológico que se verificou no século $\mathrm{XX}$-, ela será feita através dos «elementos essenciais do combate» (EEC), ou seja, dos factores técnicos susceptíveis de conferir aos equipamentos e armamentos características capazes de influenciar as tácticas e as estratégias, no emprego das forças armadas. A partir deles, pode analisar-se também o impacte das inovações tecnológicas no âmbito das estratégias integrais, incluindo os seus principais componentes: estratégias económicas, culturais e de comunicação/informação.

São cinco os elementos essenciais de combate: fogo, choque, movimento, protecção e comando/ligação. O primeiro diz respeito ao combate a distância e permite avaliar a capacidade para lançar projécteis dos equipamentos, assim como o nível dos seus alcance, precisão, cadência e potência; o choque dá a

Segundo Niall Ferguson, o conjunto de conflitos do século XX provocaram entre 167 e 188 milhões de mortos. Só as Primeira e Segunda Guerras Mundiais teriam originado entre 68 e 69 milhões ( 9 a 10 na primeira 59 na segunda).

"The Next War of the World, Foreign Affairs, Setembro/Outubro de 2005. 
possibilidade de averiguar o efeito da acção física e psicológica no contacto com o inimigo, e o grau de dificuldade com que o consegue ultrapassar; o movimento refere-se à mobilidade de um elemento combatente, abrangendo o grau de capacidade para vencer terreno difícil e obstáculos, a velocidade com que se desloca e o tipo de via que utiliza; a protecção diz respeito ao tipo de blindagem/couraça passiva que protege um elemento de combate ou uma unidade combatente; o comando/ligação respeita à capacidade dos elementos/ /unidades combatentes comunicarem entre si, e à capacidade com que se pode exercer o comando em todos os escalões, tendo em conta a respectiva natureza, qualidade, fiabilidade, alcance e amplitude.

Frequentemente, um elemento/unidade de combate é capaz de reunir vários EEC simultaneamente, uns em mais elevado grau do que outros, facto que the pode conferir vantagem no campo de batalha, como o emissor/receptor rádio, que tem maior alcance e amplitude do que o telefone, mas lhe é inferior em protecção. Por vezes, surge na panóplia militar um instrumento cuja importância no campo operacional (táctico ou estratégico) tem tal expressão, que constitui o núcleo da estrutura orgânica das unidades combatentes, sendo considerada a "arma dominante" de um período histórico. É o caso do carro de combate, que possui em alto grau as capacidades de choque, fogo, protecção e comando/ligação.

3. No início da Primeira Guerra Mundial, os EEC mais significativos não eram muito diferentes daqueles que caracterizaram a Guerra Franco-Prussiana de 1870. Com os quais os europeus, na transição dos séculos XIX/XX, mantiveram o "fardo do homem branco" e impuseram a "civilização cristã" nas regiões menos desenvolvidas do mundo, através de campanhas de pacificação.

O fogo e a protecção prevaleciam sobre o choque e o movimento. O comando/ /ligação tinha-se alargado ao telefone e utilizava o telégrafo. A comunicação a grande distância, embora de reduzida fiabilidade e protecção, efectuava-se com o telégrafo; a menor distância, usava-se o telefone (necessitava do lançamento de fio, o que poderia ser uma operação difícil e demorada), mas assegurava mais fiabilidade e segurança.

O fogo das metralhadoras (de grande cadência de tiro) a curto alcance e o da artilharia a grandes alcances, sobre as retaguardas das pequenas unidades e mais além, de grande potência e crescente precisão, aliados à protecção conferida por intensiva e extensiva fortificação de campanha e ao uso de arame farpado, detinham qualquer ataque inimigo que pretendesse romper a frente dos exércitos alinhados ao longo das trincheiras. Mesmo depois de uma rotura, normalmente de pequena dimensão, era fácil lançar contra-ataques, no interior da profundidade da zona de resistência, que a repelissem. Praticamente, nunca 
existiria guerra de movimento. Essencialmente, a Primeira Guerra foi uma guerra de posições.

As forças ofensivas, constituídas por infantaria a pé e cavalaria e transportadas para a frente por cavalos atrelados, eram impotentes para ultrapassarem as posições defensivas. A defensiva táctica e estratégica predominavam sobre a ofensiva. O movimento táctico era difícil, mas podia atingir distância expressiva, a velocidades consideráveis, no campo estratégico: no mar, com navios já a combustível líquido, e em terra, pelas vias-férreas, que cruzavam os países desenvolvidos, especialmente na Europa.

Era gigantesco o esforço logístico, para fazer chegar à frente as muitas toneladas de munições, mantimentos e material que a defensiva exigia.

Este esforço aumenta com o aparecimento do motor, na área operacional, criando a necessidade do reabastecimento de combustíveis e sobressalentes para as viaturas. $\mathrm{Na}$ batalha do Marne, foram os táxis de Paris que transportaram as tropas das unidades para a frente, permitindo o seu prolongamento, afim de evitar o torneamento das posições instaladas. A inexistência da capacidade de movimento táctico e operacional, durante a guerra franco-prussiana, tinha dado a oportunidade dos alemães envolverem os franceses, derrotando-os.

No patamar estratégico operacional, o essencial passou a ser a usura humana com a consequente usura moral, o que se repercutia no desgaste das tropas e do apoio à guerra por parte das populações, a nível estratégico integral. No patamar estratégico genético, foi necessário acentuar a capacidade industrial dos principais contendores, o que implicou uma estratégia económica de grande dimensão (na obtenção das matérias e na produção de artefactos). Para estrangular logisticamente as forças em operações, recorreu-se a grandes campanhas navais de usura (protecção e ataque às marinhas mercantes), nas quais a guerra de minas e a utilização de submarinos tiveram particular expressão A necessidade de substituir os operários que marchavam para a frente e de colmatar as numerosas baixas que a guerra provocava obrigou as mulheres a tomarem o lugar dos homens nas fábricas, o que teria repercussões estratégias de natureza social.

Para que o ataque prevalecesse sobre a defesa, fizeram-se três tentativas de superação do fogo pelo movimento. Todas elas sem êxito. Os alemães usaram o fogo com granadas de gás para paralisar os defensores, com um sucesso geográfico temporalmente restrito; os ingleses tentaram utilizar o movimento com viaturas munidas de protecção, poder de fogo e mobilidade em todo terreno (carros de combate), mas não deu resultado, por insipiência do equipamento ou o seu mau uso; ambos os contendores introduziram o movimento na terceira dimensão com meios aéreos, não conseguindo ir além da ampliação da capacidade de 
observação. Era cedo para que estas duas últimas tentativas provocassem os efeitos operacionais que surgiriam na segunda guerra mundial.

Finalmente, a associação do telégrafo com a imprensa acentuou a importância do vector estratégico psicológico, procurando atingir directamente a vontade das populações, de forma a fazê-las apoiar os nossos e odiar os inimigos. A propaganda subiu de importância.

No fim da primeira guerra mundial, assistiu-se ao desmembramento dos impérios russo, austro-húngaro e otomano, e emergiram condições sociais e políticas que conduziriam ao comunismo, fascismo e nazismo. Os Estados Unidos ascenderam a potência de primeiro plano no mundo, adquirindo o papel de protector indispensável dos países europeus ocidentais, mas não se alterou a natureza da ordem internacional, que se manteve multipolar.

Como contraponto à doutrina do "poder marítimo", da autoria do almirante Mahan, que suportara intelectualmente o imperialismo marítimo britânico, Mackinder começa a elaborar a sua doutrina do "poder terrestre". Chama a atenção para o que designa como "pivot da História", e afirma: "quem dominar a Europa de Leste domina o Heartland; quem dominar o Heartland domina a Ilha Mundial; quem dominar a Ilha Mundial domina o mundo"2.

Haushoffer observaria as relações geopolíticas centradas no equilíbrio/ /conflito entre regiões geopolíticas a que chama "pan-regiões". Elas associavam uma região desenvolvida, a Norte, com uma área de exploração, a Sul: Pan-América, Pan-África e Pan-Ásia. E avançava com o conceito de espaço vital, ao qual o nazismo foi buscar grande parte da sua elaboração intelectual.

4. O EEC movimento aparece como predominante nas primeiras campanhas da Segunda Guerra Mundial, como consequência do aperfeiçoamento de dois equipamentos experimentados na grande guerra anterior: o carro de combate e o avião. A guerra relâmpago é conduzida pelos alemães, com base no tandem avião/carro de combate, a que é essencial o aperfeiçoamento do EEC comando/ /ligação, com a melhoria da emissão/recepção rádio. Permitiu o apoio de combate dos aviões aos carros blindados, em função das suas exactas necessidades. É a guerra de movimento rápido: os elementos/unidades de combate ligadas entre si, um exercício do comando a grandes distâncias, e a obtenção atempada de apoio de fogo e de informações em todo o teatro de operações, com a arma aérea.

2 O heartland corresponde grosso modo ao "pivot" da História, localizado no centro da Europa, abrangendo parte da Alemanha e da Europa de Leste; a Ilha Mundial é outra designação da Eurásia. 
O fogo acompanha os progressos do tempo, especialmente o fogo aéreo, que prolonga o alcance da artilharia. A protecção deixa de fazer o mesmo sentido que tinha na primeira guerra mundial, embora no campo táctico ela permanecesse e se tivesse aperfeiçoado, com o recurso a elaborados campos de minas. O EEC choque também caracteriza o carro de combate, que se transforma no rei das batalhas, pela sua capacidade de protecção blindada, de movimento em todo o terreno, de fogo e de comando/ligação.

Contudo, no patamar da estratégia integral, a emissão rádio atinge uma expressão de enorme dimensão, pela possibilidade de actuar directamente na mente das populações (amigas e inimigas), permitindo tentar a manipulação (coacção) das vontades do opositor, sem intermediários, assim como a moralização (manipulação) dos cidadãos que se encontram do nosso lado.

A guerra, que se quedara, na sua primeira fase, no espaço a duas dimensões (operações em superfície, actuando apenas sobre o "corpo" do adversário, durante a primeira guerra mundial), passa a abarcar as outras duas dimensões em que se desenvolve presentemente: actuando na terceira dimensão espacial, o avião ultrapassa as frentes inimigas e é capaz de atingir o "coração" do adversário (segunda fase); com as radiações electromagnéticas, utiliza-se uma "quarta dimensão", e há a possibilidade de actuar directamente sobre a "mente" do adversário (terceira fase).

As potências aliadas contra o eixo (Alemanha e Itália, mais o Japão) responderam à enorme capacidade de movimento do inimigo, procurando aumentar a sua protecção. Para deter a ofensiva aérea contra a Grã-Bretanha, que no seu final inclui bombas voadoras (percursoras dos actuais mísseis), foi utilizado um novo equipamento, o radar, que conseguia prolongar a capacidade de vigilância antiaérea para lá do horizonte e durante a noite, com maior eficiência do que os projectores de luz. O aparecimento de armas antiaéreas especializadas, que se foram aperfeiçoando na precisão do tiro, tentava combater a capacidade de fogo e movimento do avião. Contra os carros de combate, surgiram armas anti-carro de nova tecnologia, o lança-granadas foguete (bazuca), e aperfeiçoaram-se os campos de minas.

Como resultado, as operações ofensivas perderam o ímpeto inicial e a defensiva foi retomando parte do seu anterior papel. Por vezes, a protecção não conseguia impedir a rotura de uma frente defensiva, nem era possível contra-atacar com êxito uma penetração, se o seu potencial relativo de combate fosse suficiente. O tandem avião/carro, adequadamente utilizado, continuava a ser imbatível.

Nas operações navais, a grande novidade foi a adaptação do avião para aterrar e levantar voo em grandes plataformas oceânicas (porta-aviões), que dispunham do armamento defensivo conhecido, e se rodeavam de um conjunto de unidades 
tradicionais, igualmente bem armadas, capazes as defenderem, especialmente de submarinos. O porta-aviões, núcleo essencial de um grupo de batalha, corresponde a uma ilha móvel, sobre a qual se desloca a capacidade de combate aéreo. São estes grupos de batalha que conduzem as operações navais do Pacífico; juntamente com forças do exército embarcadas, progredindo através da conquista de ilhas bem posicionadas estrategicamente, obrigaram a rendição do Japão.

Dos vectores estratégicos não militares que assumem maior expressão nesta conflagração, destacam-se o económico e o da informação.

$\mathrm{O}$ acontecimento tecnológico mais marcante da segunda guerra mundial verificou-se, contudo, no EEC fogo, com a utilização pelos norte-americanos, contra o Japão, de uma arma nova, milhares de vezes mais potente do que um explosivo convencional, que explorava novos conceitos de produção de energia, pela cisão do núcleo de átomos pesados - a bomba atómica. No rescaldo da segunda guerra mundial, será a arma atómica que marcará o novo conflito na Eurásia - a guerra-fria.

O resultado estratégico mais importante desta guerra foi a alteração da ordem internacional. Deixou de vigorar a ordem internacional de natureza multipolar. Foi substituída por uma ordem internacional bipolar, caracterizada pelo facto de apenas duas potências terem capacidade de intervenção global, os Estados Unidos e a União Soviética. Estas duas superpotências dividiriam o mundo em duas zonas de influência (dois impérios).

\section{O EEC fogo, na sua mais elevada expressão, determinará toda a estratégia durante a Guerra-fria}

Nos meses finais da segunda guerra mundial, os EUA já dispunham da arma atómica ou nuclear de cisão, no que foram acompanhados pela União Soviética, pouco depois de ela acabar. Os danos incomportáveis produzidos por esta arma, determinaram que a relação conflitual entre as duas superpotências, liderando dois poderosos pactos militares (Organização do Tratado do Atlântico Norte «OTAN» e Pacto de Varsóvia), se caracterizasse por uma situação de paz resultante do facto de se ameaçarem mutuamente com bombas nucleares - guerra-fria. Nenhuma possuía defesas capazes de impedirem o êxito dos bombardeamentos inimigos; ambas estavam em condições de promover uma estratégia contra-cidades, se, num primeiro ataque do adversário, a sua capacidade de resposta nuclear não fosse destruída. Logo, nem os EUA nem a União Soviética arriscariam desencadear um bombardeamento. Paralisavam-se um ao outro. Ou seja, dissuadiam-se mutuamente. 
A consequência foi acentuar o EEC protecção, para garantir uma capacidade de resposta que escapasse ao ataque inimigo. Dispersão, dissimulação, aumento do número de lançadores e blindagem foram os caminhos percorridos. Para responder aos progressos obtidos na protecção, procurava-se, de ambos os lados, aumentar o alcance, potência e precisão dos projécteis, multiplicar o seu número (EEC fogo), tornar os lançadores cada vez menos vulneráveis às defesas inimigas, enterrando-os em bunkers ou fazendo-os submergir algures num oceano (EEC protecção), e detectar oportunamente a iniciativa de ataque nuclear do adversário (EEC comando/ligação), para responder imediatamente.

A investigação científica desenvolvida em várias direcções conduziu a importantes aperfeiçoamentos tecnológicos com repercussão estratégica, de que devem ser destacados: possibilidade de utilização dos submarinos para lançar projécteis nucleares; passar das armas de cisão para as de fusão nuclear, cuja potência multiplicou a das anteriores, o que viria a ser exponenciado com a tecnologia das ogivas que transportavam vários projécteis com trajectórias autónomas; progressivo aumento do alcance dos mísseis, colocando várias gamas de alcances à disposição dos sistemas militares, incluindo alcances intercontinentais; enormes progressos na tecnologia de informações/comunicações, através de satélites, que permitiu o estabelecimento fácil de ligação entre qualquer ponto do planeta e com o espaço exterior, e a exploração extensiva e intensiva dos novos média, com realce para a televisão.

À dissuasão total (ameaça de destruir as cidades) foram acrescentados outros tipos de dissuasão. A dissuasão flexível ou graduada considera vários patamares de retaliação. A dissuasão proporcional entende que a destruição de apenas algumas cidades do outro será por ele entendida como um custo inaceitável. A precisão dos mísseis permitiu planear uma estratégia contra-forças (atingir os silos onde se abrigavam os lançadores de mísseis inimigos), além da estratégia contra-cidades.

O efeito de maior dimensão de toda esta panóplia nuclear nas mãos das duas superpotências era a sua paralisia para desencadear uma guerra, ou seja, tinha como resultado "não fazer a guerra". Até uma guerra convencional, pois ela, por efeito de uma escalada dos meios utilizados, poderia descambar numa confrontação atómica. É a guerra-fria. Mesmo os arsenais limitados do Reino Unido, da França, e da China inibiam um potencial atacante. Embora as armas nucleares à sua disposição só produzissem dissuasão proporcional, detinham os adversários, que nada ganhavam em destruir todo o país inimigo, em troca da destruição de algumas das suas principais cidades. A miniaturização das ogivas (e das respectivas potências) nucleares, com a finalidade de as empregar nas áreas de operações, conjuntamente com as armas convencionais, 
teve o resultado contrário do que se pretendia, pois acentuou os perigos da escalada.

O mundo passou a viver uma dissuasão pelo terror (nuclear), pela consciência de que uma guerra com este armamento poderia destruir a própria sociedade humana, tal como a conhecemos. O terror não assentava só no receio de potenciais erros no raciocínio das direcções políticas dos actores nucleares. Também se devia ao medo de erros de países aliados. Este facto obrigou as superpotências a controlarem estreitamente os conflitos periféricos. Contudo, a possibilidade de controlar estes conflitos não resolvia o perigo do desencadeamento de uma guerra nuclear por acidente ou por erro técnico ou humano.

A paralisia da estratégia militar no confronto entre as duas superpotências transferiu a disputa para outros vectores estratégicos, especialmente o económico e o psicológico através dos média, que atingiu uma enorme expressão, particularmente com o emprego da televisão.

No campo da estratégia militar, e para reduzir os perigos já mencionados de um conflito nuclear, houve a preocupação da União Soviética e dos Estados Unidos em estabelecer acordos que os evitassem. Os mais importantes foram: o tratado pelo qual as potências se comprometiam a não se armarem com equipamento que pudesse derrubar os mísseis inimigos atacantes (ABM, Anti-Balistic Missile), afim de não conferir a invulnerabilidade a nenhum dos actores, o que o tornaria impune no caso de desencadear um ataque nuclear; o acordo de limitação de armamentos nucleares e respectiva verificação (SALT, Strategic Arms Limitation Treaty), que evoluiu para o tratado de redução equilibrada dos respectivos arsenais (START, Strategic Arms Reduction Treaty), mantendo-se contudo a níveis de holocausto; o de não proliferação de armas nucleares (NPT, Non Proliferation Treaty), afim de manter um número reduzido de actores nucleares (com os subsequentes efeitos de não alterar a hierarquia de poder favorável aos actores nucleares já existentes); e o que procurava o equilíbrio das armas convencionais que se enfrentavam nos diversos teatros de operações europeus potenciais (CFE, Conventional Forces in Europe).

Esta panóplia de tratados regulamentou a dissuasão, originando um mundo estável, no respeitante a confrontações militares globais. Contudo, não cessaram as guerras, algumas de grande importância estratégica, estimuladas ou contrariadas, em maior ou menor grau, pelas duas superpotências.

As guerras de libertação das colónias europeias desempenharam um papel de primeiro plano. Incentivadas inicialmente pela União Soviética, na medida em que debilitavam aliados da OTAN, foram exploradas posteriormente pelos norte-americanos, como resposta ao seu parceiro-inimigo, dispondo-se também a partilhar o espólio dos impérios coloniais que se foram desmembrando. 
Os movimentos de libertação começaram a actuar na sequência da segunda guerra mundial, utilizando a estratégia milenar que o mais fraco sempre empregou para se impor ao mais forte - a pequena guerra ou guerra de guerrilhas. Agora mobilizada pela ideologia marxista-leninista, experimentada e teorizada por Mao Tsé-Tung, na "guerra popular" que o conduziu ao poder na China. Os princípios de emprego e as estratégias e tácticas da "guerra revolucionária" ou guerra subversiva, segundo Mao, foram a cartilha dos movimentos de libertação da Ásia e da África, que desmantelaram, primeiro os impérios coloniais britânico, francês e holandês, e, por último o português.

Apesar do seu moderno armamento e equipamento, os colonizadores não lograram êxito nas campanhas de contra-subversão, caracterizadas por uma dimensão estratégica militar de baixa intensidade (manobra militar), para garantir a segurança das acções conduzidas para conquistar os corações e as mentes das populações (manobras político-psicológica e económico-social).

O vector estratégico decisivo da guerra-fria, que ditou o seu vencedor (EUA), foi a associação da "arma económica", ligada ao esforço de manter o equilíbrio militar, com a "arma mediática". A manobra estratégica decisiva consistiu no lançamento, pelos EUA, do programa "Iniciativa de Defesa Estratégica", que ficou conhecido por "guerra das estrelas". Tratou-se de um impulso de investimento na inovação e rotura tecnológica, com a finalidade de, através da utilização do espaço para além da superfície do planeta, permitir aos EUA o levantamento de um sistema de defesa antiaérea que os tornaria invulneráveis aos ataques nucleares da União Soviética ${ }^{3}$.

Uma corrida aos armamentos, como resposta da União Soviética, provocaria tensões económicas incomportáveis, que seriam acompanhadas por tensões psicológicas e sociais resultantes do efeito das imagens televisivas que mostravam a prosperidade do Ocidente. Tensões estimuladas pelos apelos à insurreição que a Igreja católica desencadeara. A direcção política soviética foi obrigada a “ajoelhar". O império soviético desmantelou-se, entrando em recuo estratégico, ao mesmo tempo que a Alemanha, dividida desde o fim da segunda guerra mundial, se reunificou, em favor do bloco ocidental liderado pelos EUA.

Tinha dado resultado a estratégia de contenção levada a efeito pelos Estados Unidos, impedindo que a Ilha Mundial fosse dominada por um único poder, a União Soviética. A chave desta estratégia foi a manutenção do controlo do Rimland (terras costeiras) da Eurásia pela potência marítima, levando a efeito uma manobra de confronto e desgaste contra aquele que se poderia

3 Este programa foi acusado pelos soviéticos de infringir o tratado anti-míssil (ABM), o que foi terminantemente negado pelos EUA. 
considerar o poder terrestre, tal como preconizara a doutrina geopolítica do almirante Spykman.

6. Com o fim da Guerra-fria, terminava o mundo bipolar e começava um mundo novo, com os EUA, a única superpotência restante, guindada a pólo de domínio global, como centro de uma ordem internacional unipolar. Agora, isolada na capacidade de afirmação decisiva, nas várias facetas do poder: política, economia, conhecimento, investigação científica e progresso tecnológico, informação/comunicação, e militar.

Fukuyama proclamou o "fim da História", no sentido do mundo democrático e da economia de mercado ter prevalecido sobre o totalitarismo e a economia de direcção central. O que, em sua opinião, teria como efeito o amortecimento dos conflitos, a possibilidade de estender a democracia a todo o planeta e, com ela, conseguir uma estabilidade (finalmente, a paz?) com que tantos tinham sonhado.

Embora a Rússia detivesse ainda enormes arsenais nucleares, encontrava-se em recuo estratégico, nos vários domínios que enformam o potencial estratégico de um estado, nomeadamente no campo militar convencional. Os Estados Unidos possuíam e possuem um grande distanciamento relativamente a todos os outros países.

Iniciada a ordem internacional unipolar, os norte-americanos denunciaram o tratado ABM, com a finalidade de, a curto/médio prazo, estabelecerem uma defesa anti-míssil que os proteja de potências com limitados arsenais nucleares e, a médio/longo prazo, se tornem invulneráveis a qualquer ataque nuclear.

A guerra do Golfo de 1991 demonstrou esta situação de unipolaridade. À testa de uma coligação praticamente universal e "abençoada" pelas Nações Unidas, a potência "imperial" global, embora exercendo um império "benigno" (afinal, ninguém se lhe opunha), rapidamente pôs na ordem um ditador que tinha invadido um pequeno país vizinho, rico em petróleo, por coincidência um recurso estratégico cuja importância era vital em termos de poder, especialmente desde a segunda guerra mundial.

Entretanto, a investigação tecnológica corria a par da expressiva abertura de fronteiras ao comércio mundial, de acordo com a visão neoliberal que convinha à hiperpotência. A globalização, iniciada pelos descobrimentos portugueses, atinge um patamar compatível com o alargamento da influência económica e política dos Estados Unidos a todo o planeta. O desenvolvimento das comunicações transformou o mundo numa aldeia, aprofundando a globalização da comunicação/informação.

Se o EEC movimento colocava qualquer ponto do planeta e do espaço ao alcance rápido de pessoas, mercadorias, e de armas com potências variadas, 
que podiam até provocar o armagedão, também havia a possibilidade das novas tecnologias permitirem a defesa contra mísseis inimigos. E o EEC comando/ /ligação conferia a possibilidade de dar fiabilidade e capacidade de controlo a todos esses sistemas. Finalmente, a Internet vem coroar toda a evolução multimédia, exponenciado as capacidades no âmbito das comunicações, como da informação e do conhecimento.

No outro extremo, o progresso tecnológico conseguiu a miniaturização até ao limite, através dos progressos nas nano tecnologias, que propiciam a transferência de grande parte dos artefactos mais sofisticados para escalas diminutas, com dimensões da ordem da bilionésima parte do metro (10 elevado à potência de -9), construídos com moléculas orgânicas, o que permite introduzir qualidades inusitadas em todo o tipo de equipamentos e armamentos, para todos os fins, percorrendo e potenciando toda a gama dos Elementos Essenciais de Combate.

A informação sobre o campo de batalha, de todas as perspectivas possíveis, apresentada através dos instrumentos multimédia, o envio dos mais variados impulsos electrónicos a distância, as bombas de radiações (algumas não letais), a camuflagem e dissimulação que se adapta automaticamente ao ambiente envolvente, a utilização das armas químicas e bacteriológicas, além das nucleares, a biotecnologia que permite ao vestuário efectuar socorros médicos, a automação e a robótica, tudo isto começou e está a produzir materiais de combate que pertenciam ao domínio da ficção científica, a originar novos instrumentos de actuação estratégica e táctica, enfim, a provocar aquilo que se designa por "revolução nos assuntos militares", ainda em início.

O conhecimento/investigação científica passou a ser o primeiro e mais importante factor do potencial estratégico de um estado. Nele, os EUA destacam-se a grande distância de todos os outros, o que lhes permitiu conseguiram um aparelho militar imbatível nas batalhas convencionais de elevada intensidade, em qualquer dos espaços operacionais - terrestre, aéreo, marítimo, e espacial.

Entretanto, a globalização incorporou a globalização da instabilidade e da violência. Elas ultrapassam todas as fronteiras, exigindo respostas de semelhante amplitude, que se não podem circunscrever a um estado. Este, com os atributos de soberania de Vestefália, tornou-se incapaz, por si só, de resolver cabalmente os problemas para que foi organizado, nomeadamente o da segurança. As identidades pré-estatais, como etnias, religiões e culturas, voltam a ser consideradas abrigo seguro, tanto por indivíduos como por famílias. A globalização económica e a da informação/comunicação abateram as fronteiras políticas dos estados, mas, simultaneamente, permitiram a afirmação das novas entidades que, 
frequentemente, também as atravessam, cuja existência se projecta através dos meios multimédia para todo o mundo.

Actores transnacionais tendem a ocupar o vácuo gerado pela impotência dos estados-nação. Na prossecução de objectivos criminosos (máfias e gangs internacionais). E na promoção de objectivos políticos, para o que utilizam a exploração das identidades, especialmente as de natureza religiosa. Dos escombros da guerra-fria ergueram-se conflitos desterritorializados. O desmembramento da unidade política que tinha assegurado a unidade dos Balcãs e os conflitos que o acompanharam foram as suas primeiras manifestações.

Os novos actores, que retiraram todas as consequências deste ambiente de globalização, são actores não estatais, alguns deles com expressão e ambição global, como o terrorismo de base islamista, dos quais, muitos se articulam inorganicamente, numa estrutura mutante. De todos, destaca-se a Al Qaeda, organização simultaneamente directora e inspiradora, funções que se alternam em importância, em função das circunstâncias da evolução e das peripécias do confronto global em que se envolveu. Contra a ordem internacional unipolar liderada pelos norte-americanos.

É também a tecnologia que potencia a capacidade de actuação destes actores, na sistemática utilização de tácticas terroristas. Especialmente, os progressos que ela alcançou, no domínio do EEC comando/ligação, que abriram mais um teatro global de operações, o ciberespaço. A que devem ser associados os baixos custos dos mais sofisticados artefactos, derivados da sua banalização.

A possibilidade de usar viaturas terrestres, embarcações e aeronaves como armas explosivas, de fazer explodir armas sujas radiológicas e de armas nucleares, e de utilizar armas biológicas e químicas, associada à disponibilidade para o martírio ofensivo do combatente fundamentalista, fazendo-se explodir por motivos religiosos, tudo isto coloca o actor militarmente fraco em condições de desafiar os actores militarmente fortes, em termos da aplicação da violência. A que se deve acrescentar a capacidade de paralisar os sistemas informáticos que controlam a generalidade dos sistemas de apoio de vida das sociedades modernas (distribuição de água e de energia, transportes, financeiro, etc.).

A guerra assimétrica, que vem desde a mais remota antiguidade, assume uma nova dimensão. A globalização, por um lado, e a vulgarização dos artefactos que usamos na vida de todos os dias, por outro, permitem ao militarmente mais fraco enfrentar o militarmente mais forte, mesmo armado com toda a panóplia (convencional e nuclear) de que disponha.

A resposta do militarmente mais forte a estes adversários não se faz com os sofisticados sistemas militares convencionais, onde predominam os instrumentos de combate, muitos deles teleguiados e outros tantos manipulados por um 
número reduzido de soldados, em campanhas de "material intensivo". Ela exige o regresso dos numerosos efectivos terrestres, com capacidade de saturar os teatros de operações, onde se torna necessário conduzir operações preventivas de pacificação, e/ou é indispensável estabilizar teatros onde ocorreram campanhas militares de elevada ou média intensidade, através da condução de operações de pacificação pós-conflito. Tudo campanhas de "pessoal intensivo".

Por outro lado, as populações passam a desempenhar um papel de importante actor neste conflito global e transnacional, de características novas. Os métodos terroristas levados a efeito pelos actores não estatais, que visam fundamentalmente o sacrifício de inocentes, abalam a vontade das populações, que ficam apavoradas pelo medo (umas) ou incendiadas pelo extremismo religioso (outras). Como resultado, estas condicionam as atitudes e decisões das respectivas direcções políticas.

Os últimos anos do século XX caracterizaram-se por atentados que visavam especialmente os interesses dos Estados Unidos em diversas partes do mundo, ataques que funcionaram como preliminares do atentado símbolo de 11 de Setembro de 2001, data que, do ponto de vista estratégico, se pode considerar o início do século XXI.

Durante o qual não se sabe se a ordem internacional unipolar prevalecerá. O desenvolvimento económico das potências asiáticas (o Japão e os chamados tigres asiáticos antes da guerra-fria, a China e a Índia depois), o ressurgimento da Rússia, as mudanças em curso no Médio Oriente, a importância crescente dos combustíveis fósseis, e a acentuação do terrorismo catastrófico de raiz islamista, todos estes acontecimentos tornam provável que a ordem internacional unipolar venha a ser desafiada, no sentido da multipolaridade.

Resta saber se os actores políticos não estatais terão condições para fazer a confrontação evoluir para aquilo que Samuel Huntington previu no seu livro "O Choque das Civilizações". Os grandes conflitos no mundo, nas circunstâncias que surgiram com o fim da Guerra-fria, deixariam de ser entre estados, por motivos nacionais. Invocando motivos de natureza cultural, passariam a ser entre Civilizações, com a finalidade de fazer prevalecer uma "civilização" sobre outra/outras. Conflitos nos quais os estados, como componentes de uma entidade política mais vasta, também participariam. 


\section{Bibliografia recomendada}

\section{Do autor}

Apontamentos de História Para Militares - Evolução dos Sistemas de Coacção, por José Alberto Loureiro dos Santos. Lisboa, IAEM, 1979.

Incursões no Domínio da Estratégia, por José Alberto Loureiro dos Santos. Lisboa, Fundação Gulbenkian, 1983.

Segurança e Defesa na Viragem do Milénio - Reflexões sobre Estratégia II.

Mem Martins, Publicações Europa-América, 2001.

A Idade Imperial - A Nova Era - Reflexões sobre Estratégia III. Mem Martins,

Publicações Europa-América, 2003.

\section{De outros autores}

Influence de l'Armement sur l'Histoire, por J. C. Fuller. Paris, Edições Payot. Introduction à l'Histoire Militaire, por Eric Muraise. Paris, Edições Charles

Lavouzelle \& $\mathrm{C}^{\mathrm{a}}$.

The Ecyclopedia of Military History, por Dupuy e Dupuy. New York, Edições

Harper and Row.

Les Mutations de La Guerre Moderne, por Jean Perré. Edições Payot.

Armements Nucléaire et Guerre Froide, por C. Delmas.

Arms Control and Military Force. Edição do IISS

Dissuasion et Stratégie, por Beaufre.

As Forças Armadas do Estado Soviético, por Andrei Grectchko.

The Impact of New Military Technology, Edição do IISS.

The Offensive (A Soviet View), por A. A. Sidorenko, Edição sob os auspícios da Força Aérea dos EUA.

Soviet Military Strategy, por V. D. Sokolovskiy.

Strategic Thought in the Nuclear Age. Editado por Laurence Martin.

Des Stratégies Nucléaires, por Lucien Poirier.

Stratégies Soviétique et Américaine, por Henry Paris. Caderno n 17 de FEDN.

The Terrorist Reader, por Walter Laqueur. Edição da New American Library. As Tecnologias do Século XXI. Lisboa, OECD, GEPE, Ministério da Economia, 2000

Redefining European Security, editado por Hodge Carl C.. Nova Iorque, Garland Publishing, Inc., 1999.

Missile Defence and the ABM Treaty. SIPRI, Junho 2001. http://editors.sipri.se La Guerre au XXI Siècle. Paris, Edition Odil Jacob. 2000. 
Nanotechnology: Its Impact on Defence and the Mod. http://www.mod.uk Unclassified Report to Congress on the Acquisition of Technology Relating to Weapons of Mass Destruction and Advanced Conventional Munitions. http://www.odci.gov/cia/+ublications

Manual de Geopolitica e Geoestratégia - Vol. I - Conceitos, Teorias e Doutrinas, por Pedro Pezarat Correia. Quarteto, 2002, Coimbra.

Jihad: The Trail of Plitical Islam, por Giles Keppel. Harvard University Press, 2002, Boston.

A Vingança de Deus, por Giles Keppel. Publicações D. Quixote, 1992, Lisboa. Les Nouveaux Martyrs D'Allah, por Farhad Khoskhavar. Flmmarion, 2002, Paris. A Política do Ciberespaço, por Brian D. Loader. Instituto Piaget, 199, Lisboa. Estratégia Aeroespacial - Ciclos de Evolução e Perspectivas Futuras, por Rui Mora de Oliveira. Instituto de Altos Estudos da Força Aérea, 1993, Lisboa. Cibermundo: A Política do Poder, por Paul Virilio. Editorial Notícias, 199. Lisboa.

A Era da Informação: Economia, Sociedade e Cultura (2 volumes), por Manuel

Casttels. Lisboa, Fundação Gulbenkian, 2002 e 2003.

O Choque das Civilizações e a Mudança na Ordem Mundial, por Samuel P. Huntington. Lisboa, Gradiva, 2009.

Problemas Estratégicos da Guerra Subversiva, por Mao Tse-Tung. Lisboa, Sílabo, 2004.

Anthologie Mondiale de la Stratégie, coordenação de Gérard Chaliand. Paris, Robert Laffont, 1990.

Ascensão e Queda das Grandes Potências (2 Volumes), por Paul Kennedy.

Mem Martins, Publicações Europa-América, 1988.

The Post-Imperial Age, por J. P. D. Dunbabin. Londres, Longman, 1994. The Global Conflict ( $2^{\mathrm{a}}$ Ed.), por C. J. Bartlett. Londres, Longman, 1994 After Victory, por G. John Ikenberry. Princeton, Princeton University Press, 2000. The First World War, por John Keegan. Londres, Hutchinson, 1998.

The First World War, Germany and Austria-Hungary, 1914-1918, por Holger

H. Herwig. Londres, Arnold, 1997.

The Second World War, por John Keegan. Londres, Pimlico, 1989.

The Second World War, por J. F. C. Fuller. Nova Iorque, Da Capo Press, 1993. The Corean War, por Max Hastings. Londres, Pan Books, 1987.

Histoire de la Guerre d'Algérie, por Benjamin Stora. Paris, La Découverte, 2004. Contra-Insurreição em África 1961-1974, por John P. Cann. Estoril, Edições Atena, 1998.

America's Lost War Vietnam 1945-1975, por Charles E. Neu. Illinois, Harlan Davidson, 2005. 
Six Days in June, por Eric Hammel. Nova Iorque, ibooks, 1992.

La Guerre Israelo-Arabe d'Octobre 1973, por Pierre Razoux. Paris, Económica, 1999.

Conflict Unending, India-Pakistan Tensions Since 1947, por Sumit Ganguly. Washington DC, Oxford University Press, 2001.

The Argentine Fight for the Falklands, por Martin Middlebrook. Barnsley, Pen \& Sword, 2003.

Uma História da Guerra, por John Keegan. Lisboa, Edições Tinta da China, 2006. 